\title{
PERAN PUSTAKAWAN DALAM PERKEMBANGAN PERGURUAN TINGGI
}

\author{
S. Manaf \\ Institut Agama Islam Negeri (IAIN) Metro \\ Email: s.manaf@gmail.com
}

\begin{abstract}
Abstrack
The role of the Librarian, has progressed over time. Now librarians are not only serving the circulation of books, but are required to be able to provide information quickly, precisely, accurately, and efficiently in terms of time and cost. Librarians are required to develop competence in themselves in order to support the implementation of tertiary education programs. Competency and librarians play an important role in supporting the achievement of the vision of higher education. In this paper, it is explained and explained matters relating to the competence and role of librarians in supporting the establishment of international universities. Also explained the problems faced by librarians, problem analysis, solutions, and efforts that must be made to achieve goals in support of international universities.
\end{abstract}

Keywords: Librarian, University

\begin{abstract}
Abstrak
Peran Pustakawan, semakin berkembang dari waktu ke waktu. Kini pustakawan tidak hannya melayani sirkulasi buku, tetapi dituntut untuk dapat memberikan informasi secara cepat, tepat, akurat, dan efisen dari segi waktu dan biaya. Pustakawan di tuntut untuk mengembangkan kompetensi yang ada dalam dirinya guna mendukung pelaksanaan program tridarma perguruan tinggi. Kompetensi dan pranpustakawan sangat berperan dalam mendukung tercapainya visi perguruan tinggi. Dalam tulisan ini dipaparkan dan di jelaskan hal-hal yang berkaitan dengan kompetensi dan peran pustakawan dalam mendukung terwujudnya perguruan tinggi bertaraf internasional. Di jelaskan pula permasalahan yang di hadapi pustakawan, analisis masalah, solusi, serta upaya yang harus dilakukan guna meraih tujuan dalam mendukung perguruan tinggi bertaraf internasional.
\end{abstract}

Kata Kunci: Pustakawan, Perguruan Tinggi

\section{A. Pendahuluan}

Pada era global ini, pendidikan merupakan sesuatu yang penting. Karena pendidikan merupakan akar dari peradaban sebuah bangsa. Pendidikan telah menjadi kebutuhan dasar yang setiap orang harus memiliki untuk memenuhi tantangan kehidupan.Untuk pendidikan, banyak cara yang dapat kita capai. Termasuk di perpustakaan. Karena di perpustakaan berbagai sumber informasi bisa kita dapatkan, di samping banyak manfaat lain yang bisa diperoleh melalui perpustakaan. Ketika kita mendengar kata perpustakaan, pikiran kita langsung terbayang deretan buku tersusun rapi di rak-rak sebuah ruangan. Pandangan ini tampaknya benar, tetapi jika kita memperhatikan lebih, itu selesai. Karena setumpuk buku yang diatur di rak-rak perpustakaan tidak bisa disebut sebagai perpustakaan. 
Bahkan, konsep perpustakaan kadang-kadang bingung dengan istilah jangka panjang, pustakawan, pustakawan, dan ilmu perpustakaan. Secara harfiah, perpustakaan sendiri sedang dipertimbangkan sebagai gedung perpustakaan fisik - buku atau bahan pustaka. Untuk tujuan ini, pembahasan kali ini akan dibahas secara mendalam di perpustakaan pengenalan umum meliputi: memahami perpustakaan, maksud dan tujuan penciptaan perpustakaan, jenis - jenis fungsi perpustakaan, tugas dan fungsi perpustakaan, kegiatan utama perpustakaan, dan perpustakaan sebagai suatu disiplin.

Visi IAIN Metro menjadi pusat pengembangan ilmu pengetahuan, ilmu, agama, teknologi dan seni, yang menonjol internasional berdasarkan nilai-nilai luhur, budaya nasional mengacu pada visi universitas secara umum Anda ingin mencapai tingkat nasional antara lain. Jelas kebutuhan yang ditargetkan, kerjasama direncanakan, kerjasama, sinergi, dan terus di antara semua guru akademik. Perpustakaan sangat penting dalam mendukung pengetahuan dan informasi dari siswa di pendidikan tinggi, dan karena itu perpustakaan sering disebut sebagai jantung pendidikan. Di universitas, perpustakaan merupakan bagian yang tidak terpisahkan dari proses pendidikan. Perpustakaan adalah fasilitas baik untuk siswa atau guru sebagai pemustaka untuk mendukung pengajaran dan pembelajaran di pendidikan tinggi. Joseph (2007, p. 3) menunjukkan bahwa tujuan dari pembentukan "perpustakaan universitas tidak dapat dipisahkan dari tujuan diselenggarakannya pendidikan tinggi secara keseluruhan, yaitu untuk penyediaan keterampilan dasar kepada siswa dan mempersiapkan mereka untuk pendidikan menengah ". Lebih jelas, Prastowo, mengatakan bahwa "perpustakaan universitas adalah fasilitas pendidikan nyata yang membantu menentukan pencapaian tujuan dari lembaga perlindungan." Oleh karena itu, diharapkan bahwa perpustakaan untuk menciptakan kondisi yang sepenuhnya mendukung pencapaian proses pembelajaran yang efektif di universitas. Dalam rangka mendukung perpustakaan universitas, menurut kurikulum dan pembelajaran, harus tahu bagaimana peran, tujuan, fungsi perpustakaan universitas itu sendiri. Peran perpustakaan universitas adalah untuk memenuhi kebutuhan informasi dari pengguna, dalam hal ini siswa dan guru dalam mendukung kegiatan proses belajar di universitas. Peran penting dari perpustakaan tidak dapat dipisahkan dengan fasilitas dan pelayanan yang ditawarkan perpustakaan. Jadi perpustakaan dapat menjadi sasaran penting dalam mencari informasi tentang pendidikan tinggi.

Pesatnya perkembangan perpustakaan seiring dengan perkembangan ilmu pengetahuan, pemustaka dapat mengambil keuntungan dari perpustakaan dengan baik dan bijaksana sesuai dengan kebutuhan pemustaka. Untuk ini kita perlu keprihatinan yang mendalam untuk kebaikan perpustakaan manajer atau staf perpustakaan untuk dapat memberikan bimbingan yang lebih baik kepada siswa menggunakan perpustakaan secara efektif dan efisien. Alamat yang diberikan tentunya sesuai dengan kebutuhan siswa dan bukan hak dan 
kewajiban siswa dan pengguna perpustakaan. Alamat yang diberikan untuk bagaimana menggunakan fasilitas yang disediakan oleh perpustakaan, bagaimana mencari dan menerima informasi dapat diperoleh di perpustakaan, dan bagaimana menggunakan koleksi yang tersedia di perpustakaan. Oleh karena itu, peran pustakawan sangat penting, bagaimana dapat memberikan bimbingan yang tepat dan dapat diterima oleh siswa. Kemudian pengetahuan tentang karakteristik dan kebutuhan siswa akan membuat penyediaan langkah yang menentukan dalam membimbing siswa.

Arah pustakawan, pemustaka harapan untuk membuat motivasi lebih untuk menggunakan perpustakaan yang terpisah dan aman dan mempercepat proses pencarian informasi yang mereka butuhkan. pendidikan pemustaka untuk aplikasi ini sangat penting untuk mendukung pemenuhan kebutuhan informasi secara memadai. Menurut Sutarno (2006 hlm.215), "memberikan pendidikan pengguna, kegiatan yang dilakukan oleh petugas servis untuk menjelaskan rincian dari perpustakaan. Diantara manfaat perpustakaan, bagaimana menjadi anggota, persyaratan keanggotaan, peraturan, jenis layanan dan partisipasi masyarakat di perpustakaan. "

Tujuan pendidikan dapat membuat pemustaka perpustakaan yang lebih maju dan dapat digunakan secara optimal untuk siswa. pendidikan pemustaka tidak diragukan lagi memperluas siswa bahwa perpustakaan tidak hanya sekelompok bangunan yang menyimpan buku-buku, tetapi perpustakaan merupakan bagian penting yang tidak dilepaskan dari kegiatan siswa dalam proses belajar dan hal-hal lain yang dapat bermanfaat untuk memahami informasi.

\section{B. Pembahasan}

\section{Pengertian Pustakawan}

Pustakawan adalah seseorang yang bekerja di perpustakaan dan bantuan orang menemukan buku, majalah dan informasi lainnya. Di tahun 2000-an, pustakawan mulai membantu orang menemukan informasi menggunakan komputer, database elektronik dan perangkat pencarian Internet. Ada berbagai jenis pustakawan, antara anak-anak lainnya, remaja, dewasa, sejarah, hukum, dll Wanita Pustakawan bernama pustakawan.

Menjadi seorang pustakawan, seseorang perlu dididik tentang tingkat perpustakaan S2 dan D2. Kebanyakan pustakawan yang bekerja di perpustakaan di perguruan tinggi, universitas, atau tingkat kota, provinsi dan negara. Beberapa pustakawan bekerja untuk perusahaan swasta untuk membantu mereka mengelola dokumen dan laporan.

a. Menurut kamus besar Bahasa Indonesia pustakawan adalah orang yang bergerak di bidang perpustakaan atau ahli perpustakaan.

b. Kemudian menurut kode etik Ikatan Pustakawan Indonesia dikatakan bahwa yang disebut pustakawan adalah seseorang yang melaksanakan 
kegiatan perpustakaan dengan jalan memberikan pelayanan kepada masyarakat sesuai dengan tugas lembaga induknya berdasarkan ilmu perpustakaan, dokumentasi dan informasi yang dimilikinya melalui pendidikan.

c. menurut kamus istilah perpustakaan karangan Lasa, H.S. Librarian pustakawan, penyaji informasi adalah tenaga profesional dan fungsional di bidang perpustakaan, informasi maupun dokumentasi. Dari ketiga pengertian di atas dapat disimpulkan bahwa pustakawan adalah orang yang memiliki pendidikan perpustakaan atau ahli perpustakaan atau tenaga profesional di bidang perpustakaan dan bekerja di perpustakaan. Jadi pustakawan adalah seseorang yang profesional atau ahli dalam bidang perpustakaan.

d. Menurut Pandji Amoraga dalam psikologi kerja bahwa profesional mengharuskan tidak hanya pengetahuan dan keahlian khusus melalui persiapan dan latihan, tetapi dalam arti profesional terpaku juga suatu panggilan, suatu calling, suatu strong inner impulse yang pertama adalah unsur keahlian dan kedua unsur panggilan. Sehingga seorang profesional harus memadukan dalam diri pribadinya kecakapan teknik yang diperlukan untuk menjalankan pekerjaannya, dan juga kematangan etika. Penguasaan teknik saja tidak membuat seseorang menjadi profesional keduanya harus manunggal. Jadi seorang pustakawan yang profesional tidak hanya dituntut untuk menguasai penguasaan teknik perpustakaan saja, tetapi juga harus mempunyai kematangan etika, harus merasa terpanggil untuk menjadi pustakawan karena pustakawan adalah pelayan masyarakat yang selalu berhadapan dengan berbagai kalangan masyarakat. Sehingga dengan demikian pustakawan akan disenangi oleh masyarakat pengguna perpustakaan.

e. Poerwadarminta dalam menambahkan bahwa, "Pustakawan adalah ahli perpustakaan. Dengan pengertian tersebut berarti pustakawan sebagai tenaga yang berkompeten dibidang perpustakaan, dokumentasi, dan informasi". Selanjutnya Aziz menambahkan bahwa, "Pustakawan merupakan tenaga profesi dalam bidang informasi, khususnya informasi publik, informasi yang disediakan merupakan informasi publik melalui lembaga kepustakawanan yang meliputi berbagai jenis perpustakaan".

\section{Kompetensi Pustakawan}

Kompetensi didefinisikan sebagai pengetahuan, keterampilan dan nilainilai inti tercermin dalam kebiasaan berpikir dan bertindak. Arti lain dari yurisdiksi adalah spesifikasi dari pengetahuan, keterampilan dan sikap seseorang dan penerapannya dalam pekerjaan, sesuai dengan standar kinerja yang dibutuhkan oleh pengadilan. 
Berdasarkan pemahaman ini, standar kompetensi pustakawan adalah pernyataan kriteria yang dibutuhkan ditentukan dan disepakati dalam bentuk akuisisi pengetahuan, keterampilan dan sikap untuk pustakawan untuk dipanggil kompeten.

Tujuan dari standar adalah kompetensi pustakawan sebagai jaminan terhadap pemustaka memberikan pelayanan terbaik, untuk menciptakan perpustakaan suasana, memberikan copy dan mempertahankan reputasi lembaga dan posisi sesuai dengan tugas dan tanggung jawab.

Kompetensi dapat dibagi menjadi dua jenis. Ketik pertama disebut keterampilan 'soft skill'. Ketik kompetensi ini berkaitan dengan kemampuan untuk mengatur proses kerja dan berinteraksi dengan orang lain. Termasuk dalam keterampilan umum meliputi kemampuan manajemen, kemampuan memimpin (leadership), kemampuan komunikasi, dan kemampuan untuk hubungan membangun dengan orang lain (interpersonal). Sedangkan tipe kedua keterampilan yang "keterampilan yang sulit." Jenis kedua keterampilan yang berkaitan dengan kapasitas fungsional atau pekerjaan teknis. Dengan kata lain, yurisdiksi teknis yang berkaitan dengan pekerjaan digelar. Contoh keterampilan yang sulit di bidang perpustakaan, antara lain, kemampuan untuk mengklasir, katalog, mengindek, abstrak, data entry, pemustaka layanan, mencari, dll informasi.

Dari perspektif lain, keterampilan Asosiasi Perpustakaan Khusus membedakan ke dalam kompetensi profesional dan / kompetensi individual pribadi. kompetensi profesional adalah keterampilan pada pengetahuan pustakawan di bidang sumber daya informasi, teknologi, manajemen dan penelitian, dan kemampuan untuk menggunakan pengetahuan sebagai dasar untuk menyediakan layanan informasi dan Perpustakaan. Sementara keterampilan pribadi keterampilan yang menggambarkan kesatuan keterampilan, sikap dan nilai-nilai yang pustakawan untuk bekerja secara efektif, menjadi komunikator yang baik, terus-menerus meningkatkan pengetahuan, dapat memperhatikan nilai sisa, dan dapat menahan perubahan dan perkembangan di dunia kerja.

Di perpustakaan hukum mencatat bahwa pelaksanaan, manajemen, perpustakaan pengembangan perpustakaan berdasarkan standar nasional. Titik adalah staf dari standar nasional perpustakaan perpustakaan standar. penjelasan yang lebih rinci dari Undang-Undang menyatakan bahwa staf perpustakaan referensi standar termasuk kualifikasi akademik, kompetensi dan sertifikasi. Hal ini jelas bahwa kompetensi pustakawan merupakan elemen penting, selain kualifikasi akademik dan sertifikasi. Pertanyaannya adalah bagaimana mengukur pustakawan kompeten atau tidak? Oleh karena itu, kita perlu standar kompetensi pustakawan.

Untuk menemukan pustakawan kompeten atau tidak, bagaimana tingkat keterampilan yang diperlukan untuk referensi. Referensi disebut standar. 
standar pustakawan kompetensi mereka sangat penting. Setidaknya tiga pihak yang memiliki kepentingan dengan standar kompetensi pustakawan. Yang pertama adalah perpustakaan. Untuk perpustakaan, pustakawan standar kompetensi dapat digunakan sebagai panduan bagi pustakawan untuk merekrut dan mengembangkan program pelatihan bagi staf perpustakaan memiliki keterampilan atau meningkatkan keterampilan mereka. yang kedua adalah mengorganisir lembaga sertifikasi pustakawan. Untuk sertifikasi pustakawan, standar kompetensi pustakawan dapat digunakan sebagai acuan untuk mengevaluasi kinerja pustakawan dan pustakawan uji sertifikasi. Sedangkan ketiga adalah pustakawan. Pustakawan untuk standar pustakawan kompetensi dapat digunakan sebagai acuan untuk mengukur kemampuan untuk menduduki jabatan pustakawan.

Sayangnya, standar kompetensi pustakawan di Indonesia masih sedang disusun. Namun, dalam rangka untuk memaksa perpustakaan dan pustakawan dapat mempersiapkan tertunda standar kompetensi pustakawan, perlu untuk mengetahui apa keterampilan yang harus dipenuhi oleh seorang pustakawan. Asosiasi Perpustakaan pada tahun 2003 didefinisikan keterampilan pustakawan khusus. Meskipun formulasi ini secara efektif sebutan untuk pustakawan yang bekerja di perpustakaan khusus, tetapi dapat digunakan sebagai referensi sementara dan tentunya membutuhkan beberapa penyesuaian. Seperti yang telah disebutkan di atas bahwa keterampilan Asosiasi Perpustakaan Khusus membedakan menjadi dua jenis, yaitu kompetensi profesional dan / kompetensi individual pribadi.

Berikut adalah kompetensi profesional yang seharusnya dimiliki oleh pustakawan:

a. Memiliki pengetahuan keahlian tentang isi sumber-sumber informasi, termasuk kemampuan untuk mengevaluasi dan menyaring sumbersumber tersebut secara kritis.

b. Memiliki pengetahuan tentang subjek khusus yang sesuai dengan kegiatan organisasi pelanggannya.

c. Mengembangkan dan mengelola layanan informasi dengan baik, accessable (dapat diakses dengan mudah) dan cost-effective (efektif dalam pembiayaan) yang sejalan dengan aturan strategis organisasi.

d. Menyediakan bimbingan dan bantuan terhadap pengguna layanan informasi dan perpustakaan.

e. Memperkirakan jenis dan kebutuhan informasi, nilai jual layanan informasi dan produk-produk yang sesuai kebutuhan yang diketahui.

f. Mengetahui dan mampu menggunakan teknologi informasi untuk pengadaan, pengorganisasian, dan penyebaran informasi.

g. Mengetahui dan mampu menggunakan pendekatan bisnis dan manjemen untuk mengkomunikasikan perlunya layanan informasi kepada manajemen senior. 
h. Mengembangkan produk-produk informasi khusus untuk digunakan di dalam atau di luar lembaga atau oleh pelanggan secara individu.

i. Mengevaluasi hasil penggunaan informasi dan menyelenggarakan penelitian yang berhubungan dengan pemecahan masalah-masalah manajemen informasi.

j. Secara berkelanjutan memperbaiki layanan informasi untuk merespon perubahan kebutuhan.

k. Menjadi anggota tim manajemen senior secara efektif dan menjadi konsultan organisasi di bidang informasi. Sebelas butir di atas tidak semuanya harus dimiliki oleh seorang pustakawan Kemampuan, yang harus dimiliki seorang pustakawan mesti disesuaikan dengan tingkatan atau levelnya

Sedangkan kompetensi personal/individu bagi pustakawan meliputi:

1) Memiliki komitmen untuk memberikan layanan terbaik.

2) Mampu mencari peluang dan melihat kesempatan baru baik di dalam maupun di luar perpustakaan.

3) Berpandangan luas.

4) Mampu mencari partner kerja.

5) Mampu menciptakan lingkungan kerja yang dihargai dan dipercaya.

6) Memiliki ketrampilan bagaimana berkomunikasi yang efektif.

7) Dapat bekerjasama secara baik dalam suatu tim kerja.

8) memiliki sifat kepemimpinan.

9) mampu merencanakan, memprioritaskan dan memusatkan pada suatu yang kritis.

10) memiliki komitmen untuk selalu belajar dan merencanakan pengembangan kariernya.

11) mampu mengenali nilai dari kerjasama secara profesional dan solidaritas.

12) memiliki sifat positif dan fleksibel dalam menghadapi perubahan.

\section{Peran Pustakawan}

Peran Pustakawan membantu pengguna untuk mendapatkan informasi dari cara diarahkan sebagai pencarian informasi bisa efektif, efisien, efektif dan tepat waktu. Dengan perkembangan informasi, peran pustakawan tegnologi lebih diperkuat sehingga dapat bekerja sebagai mitra bagi para pencari informasi. Sebagai fungsi tradisionalnya, pustakawan dapat pecari langsung untuk Sohih informasi dan informasi bertanggung jawab.

Pustakawan juga dapat memberikan informasi yang dapat berguna, tetapi kehadirannya sering tersembunyi, sebagai sastra abu-abu (grey literature). Bahkan pustakawan dapat berfungsi sebagai mitra penelitian dalam penelitian. Mengacu pada di atas, jelas bahwa hubungan erat antara pustakawan sebagai 
manajer informasi dalam perannya dalam Tri Dharma dukungan pendidikan tinggi.

Selain melakukan pelayanan lalu lintas, pengadaan dan pengolahan bahan pustaka, pustakawan harus mampu menangani laporan administrasi; mengelola Web OPAC catatan retensi menjadi (termasuk pengolahan dokumen telah menjadi bentuk digital). Mengelola layanan dan pinjaman antar (PAP) untuk memantau keamanan bahan pustaka, mengelola media (CD / DVD / kaset audio / X-ray) mengelola dan kode bar cetak, mengelola keanggotaan pengguna, penyusunan anggaran make, membuat katalog (pra dan katalog posting) ke layanan SDI untuk mengkonversi data email mengengola, membuat laporan, mengelola waktu ke waktu, setiap hari, setiap minggu, setiap bulan.

Dengan lembar kinerja rutin diisi oleh pustakawan setiap hari, mau tidak mau, pustakawan didorong untuk menyelesaikan tugas dengan sebaik-baiknya. Laporan ini dapat menjadi indikator kinerja, produktivitas dan peran pustakawan dalam profesi mereka.

Peran pustakawan sebagai mitra bagi siswa, guru dan masyarakat sekitar, diakui lebih baik tahun -ketahun, hal ini tercermin dalam meningkatnya jumlah pengguna yang menggunakan layanan perpustakaan, cetak dan dokumen elektronik datang langsung keperpustakaan atau tidak langsung (untuk sastra melalui e-mail atau browsing katalog online), misalnya, statistik pengunjung perpustakaan pada tahun 1998 adalah 16200 orang pada tahun 1999, 2000 Total 224,5 255,4 264204 orang-tahun dan 2005 adalah 248,02 orang.

Dari data tersebut, tampaknya tren jumlah pengunjung meningkat 19982005 dan berikut untuk 20.019 jumlah pengunjung dapat meningkat indikator kualitas layanan yang terkait dengan kompetensi dan peran pustakawan dalam melaksanakan fungsinya.

Pada dasarnya, pustakawan adalah orang yang bekerja perpustakaan disebuah atau pusat-pusat dokumentasi dan informasi lainnya dengan kondisi tertentu. Di lapangan, peran pustakawan dapat melayani penggunanya dengan berbagai cara. Sebagai contoh, dalam sebuah lembaga perpustakaan perguruan tinggi, selain bertindak sebagai pustakawan biasanya dapat juga berfungsi ganda sebagai pembicara. Sebuah perguruan tinggi juga dapat ganda sebagai dosen atau peneliti. Di Perpustakaan Khusus, disamping sebagai pustakawan, dapat pula menjadi peneliti, minimal sebagai mitra peneliti. Dengan demikian pustakawan memiliki peran ganda yang dapat disingkat dengan akronim EMAS dengan penjelasan sebagai berikut:

a. Edukator. Dalam hal ini pustakawan dalam setiap melaksanakan tugasnya harus bisa mempunyai jiwa pendidik, Ia harus melaksanakan fungsi pendidikan yaitu mendidik, mengajar dan melatih. Mendidik adalah mengembangkan kepribadian baik kepada pemustaka ataupun yang lain, mengajar adalah mengembangkan kemampuan berfikir dan melatih adalah membina dan mengembangkan keterampilan. Sebagai 
pustakawan pendidik, pustakawan juga harus memahami prinsipprinsip yang dikembangkan oleh Ki Hajar Dewantara, yaitu Ing Ngarsa Sang Tuladha, Ing Madya Mangun Karsa, Tut Wuri Handayani.

b. Manajer. Pada hakikatnya pustakawan adalah manajer informasi yang mengelola informasi pada satu sisi, dengan pengguna informasi pada sisi lain. Dalam hal ini pustakawan harus bisa mengelola informasi yang berada di perpustakaaan dengan baik, agar para pemustaka mudah dalam menemukan informasi yang ia cari. Pustakawan dalam peranannya sebagai manajer juga harus dapat memanajemen dengan baik, artinya ia harus dapat mengawasi sumber daya yang tersedia, baik sumber daya manusia, atau sumber daya lainnya secara optimal dan efisien agar visi dan misinya dapat tercapai.

c. Administrator. Sebagai administrator, pustakawan harus mampu menyusun, melaksanakan dan mengevaluasi program perpustakaan, serta dapat melakukan analisis atas hasil yang telah dicapai, kemudian melakukan langkah-langkah untuk mencapai visi dan misinya. seorang pustakawan harus mempunyai pengetahuan yang luas dibidang organisasi, sistem dan prosedur kerja. Dengan demikian setiap pekerjaan atau tugas yang dihadapinya dapat terselesaikan dengan mudah dan berkualitas.

d. Supervisor Sebagai supervisor, maka pustakawan harus melakukan halhal sebagai berikut; Dapat melaksanakan pembinaan professional, untuk mengembangkan sikap kerukunan dan kerja sama antar pustakawan. Sehinnga dalam melaksanakan tugasnya dapat berjalan lancar sesuai dengan prosedur.Dapat meningkatkan prestasi, pengetahuan dan ketrampilan, baik antara sesama pustakawan atau kepada para pemustaka.Mempunyai Ilmu atau wawasan yang luas serta bersikap sabar tetapi tegas, adil dan obyektif dalam melaksanakan tugasnya. Mampu berkoordinasi dengan baik, sehingga ketika ada masalah ataupun kendala, dapat terselesaikan dengan mudah.

\section{Simpulan}

Pustakawan sangat berharap standar mereka dan memegang sertifikat kompetensi pustakawan.Dengan keselarasan dari semua elemen (profesionalisme sumber daya manusia, infrastruktur dan fasilitas modern, serta sarana subsistensi dan pendanaan yang memadai cukup memadai) mungkin percaya, visi perguruan tinggi mencapai tingkat internasional akan tercapai. keterampilan pustakawan jika dibangun dan mapan, itu akan dapat membantu mencapai perguruan tinggi internasional. Sulit untuk masuk, tidak semudah membalikkan telapak tangan. Semuanya harus dicari dan diperjuangkan, dibutuhkan waktu dan sedikit pengorbanan untuk mencapai visi perguruan tinggi dengan kompetensi dan peran pustakawan. 


\section{Referensi}

Departemen Pendidikan dan kebudayaan. Kamus besar Bahasa Indonesia. Jakarta: Balai pustaka. 1989

Etienne Wenger, (et.al.). Cultivating communities of practice: a guide to managing knowledge. Boston: Harvard Business School Press. 2002.

Hartono. Menggali Potensi Pustakawan Menuju Manajemen Perpustakaan Profesional. Buletin, 2015.

Hendro Wicaksono, Kompetensi Perpustakaan Dan Pustakawan dalam Implementasi Teknologi Informasi di Perpustakaan. Perpustakaan Nasional : Majalah Visi Pustaka Edisi : Vol. 6 No. 2 - Desember 2004.

http:// www.growthcopusoft.com/librarian/management Diakses 22

Indonesia.Perpustakaan Nasional.http://www.pnri.go.id/.Diakses tanggal 23 Maret 2006.

Lien, Diao Ali. Peranan Perpustakaan dalam meningkatkan Daya saing Perguruan Tinggi. Maret.2006

Marshall, Joane; Linda Moulton; Roberta Piccoli. Kompetensi Pustakawan Khusus di Abad Ke-21.BACA.Jurnal Dokumentasi vol.27(2),2003.

Perpustakaan Nasional RI. Keputusan Menteri Tenaga Kerja dan Transmigrasi Republik Indonesia Nomor 83 Tahun 2012 tentang Penetapan Rancangan Standar Kompetensi Kerja Nasional Indonesia Sektor Jasa Kemasyarakatan, Sosial Budaya, Hiburan, dan Perorangan Lainnya Bidang Perpustakaan menjadi Standar Kompetensi Kerja Nasional Indonesia. Jakarta: Perpustakaan Nasional RI. 2012.

Perpustakaan Nasional RI. Naskah Akademik Rancangan Undang-Undang Perpustakaan, 2006.

Sri Rumani,. Sertifikasi Profesi Pustakawan Berbasis Kinerja Sebagai Upaya Menghadapi Era Global. Perpustakaan Nasional RI : Media Pustakawan Vol. 21 No. 2 Tahun 2014. 